\title{
Epithelial Cells to Total Cells Ratio Measurement
}

National Cancer Institute

\section{Source}

National Cancer Institute. Epithelial Cells to Total Cells Ratio Measurement. NCI

Thesaurus. Code C130161.

The determination of the ratio of epithelial cells compared to total cells in a sample. The measurement may be expressed as a ratio or percentage. 